\title{
Catholic Church Services in Pandemic Coronavirus Disease (Covid-19) in the Diocese Ruteng - Indonesia
}

\section{Salesman $\mathrm{F}^{1 *}$ and Tapung $\mathrm{MM}^{2}$}

${ }^{1}$ Professor in Public Health, Universitas Citra Bangsa, Indonesia

${ }^{2}$ Lecturer in Sociology, Universitas Santu Paulus Ruteng, Indonesia

*Corresponding author: Frans Salesman, Professor in Public Health, Universitas Citra Bangsa, Indonesia, Email: franssalesman@gmail.com

\section{Research Article}

Volume 4 Issue 2

Received Date: February 01, 2021

Published Date: March 17, 2021

DOI: $10.23880 /$ jqhe- 16000208

\section{Abstract}

The Covid-19 pandemic affected the coastal communities in Manggarai. The bargaining power of fish catches and crop yields in the field has decreased. This situation makes it difficult for them to survive. Concerned about this situation, the Catholic Church of Diossece Ruteng formed a task force as a social worker to provide basic food assistance, medicines, personal protective equipment, and advocate healthy behavior for Catholics in the diocese of Ruteng.

Purpose: Exploring the types of basic needs of coastal communities, continued to provide food aid to reduce the suffering of coastal communities affected by Covid-19.

Method and Materials: Using a modification of the IPOAFI model (Identifying, Planning, Organizing, Acting, Finding, Impact). Providing social assistance and advocating for health behavioral education.

Results: Reducing the suffering of coastal communities of food shortages, increasing knowledge about Covid-19, cultured hand washing, wearing masks, maintaining body immunity by consuming nutritious food, routine health checks. Conclusion. The presence of the Catholic Church in Diossece Ruteng helped the suffering of the people affected by Covid-19.

Keywords: Covid-19; Catholic; Church; Solidarity; Task Force

\section{Introduction}

The Covid-19 pandemic has spread to 213 countries in the world. As an infectious disease, Covid-19 not only increases human mortality and morbidity, it also results in erosion of socio-economic resilience and increased poverty in a country. Indonesia, with a population of 273 million, has experienced disruption of the economic production chain, a decline in national and international tourism activities, restrictions on mobility through psychical distancing and social distancing, decreased quality of human capital, increased market distrust [1]. All industries stopped producing. Demand is weak, sales and business revenues are declining, and many companies are losing money. Unemployment occurs everywhere. Workers who bear 8 million family members lose nutritional supplies and are not met by other essential needs in the family due to loss of employment. Poverty happens everywhere.

The Diocese Ruteng as one of 38 dioceses in Indonesia with populations 840,000 Catholics are concerned about the suffering suffered by their people as a result of pandemic the Covid-19. Before the pandemic, the number of poor people in the diocese was $21.09 \%$, with a poverty index of $0.97 \%$ and a severity index of $0.99 \%$. The average per capita income of the poor is IDR 3,118,072 per month [2]. During the pandemic covid-19, poverty rates increased due to unemployment, rising prices for basic necessities. According to the teachings of the church, according to Gregory the Great (VI century) in the concept of caring for the soul, the body is the home of the soul. Humans are soul bodies. Humans are a unified whole of soul and body [3]. A healthy soul is found in a healthy body. If 
the body is sick, then the soul also hurts, and in time he will leave the body. Humans die. The local Church of the Diocese Ruteng has a great responsibility in caring for the bodies of its people.

The Catholic Church defines the Church as "the assemblage of people who are moved to gather together by the Word of God to form the People of God and who are confirmed by eating with the Body of Christ every ecclesiastical ritual." The association of God's people takes part in living worship that sanctifies (Liturgia), develops the proclamation of the Good News (Kerygma), presenting and building fellowship (Koinonia), advancing the work of love/ service (Diaconia) and witnessing (Martyria). One of the diacons' duties is carried out by the church and ultimately is carrying out charitable work/charity through various Christian charity activities, especially for those who are poor, neglected, and marginalized, and experience suffering due to natural and non-natural disasters. Through the field of deaconess work, the faithful are aware of their personal responsibility for the welfare of their fellowmen. Therefore it requires cooperation in love, openness full of empathy, participation and sincerity to share with one another for the benefit of all Catholics.

This is the biblical basis, Bishop Ruteng formed a task force to distribute aid to help the poor and affected by the corona-19 virus pandemic in the Ruteng diocese. Through Instruction Bishop Ruteng Siprianus Hormat Number. 001 / I.1 / III / 2020 related to the Covid-19 outbreak, in the form of a task force to mobilize the Solidarity Movement in the Ruteng Diocese Church. The promotion of solidarity starts from the person of the community/community, parishes, monasteries, Catholic foundations and parishioners, and interfaith followers who have good intentions and will. The form of involvement was carried out through various promotional activities, prevention, education and social assistance actions of Covid-19 in the form of materials such as Personal Protective Equipment (masks, special coats, gloves, disinfectant liquids, hand sanitizers), groceries, and financial assistance for Corona victims and groups vulnerable-deficient. The purpose of the Analyze the role of the Catholic Church task force in the diocese of Ruteng to help channel food, medicines, personal protective equipment, and advocate healthy behavior for Catholics affected by Covid- 19 .

\section{Method and Materials}

Using quantitative and qualitative descriptive methods. In-depth Catholic religious leaders were conducted indepth interviews to obtain information on the situation of the family during the pathogenesis of Covid-19 in their area of residence. Activities carried out four stages, namely; (1) Coordination; (2) Action which consists of promotion, prevention, education and social assistance activities; (3) Evaluation; and (4) Proposed Activity Plan. The design of activities follows the flow chart 1 below.

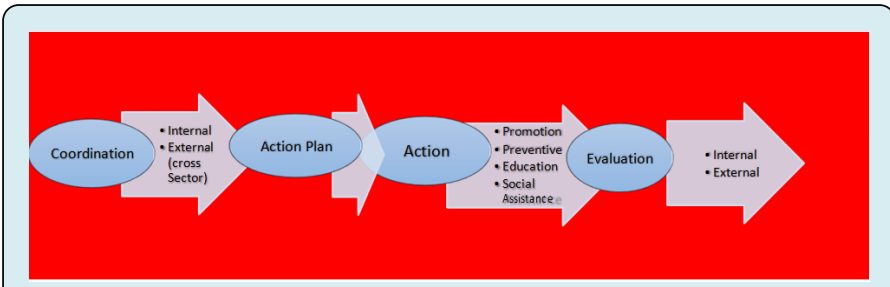

Flow Chart 1: Flow of the Task Force Covid-19 of Diocese Ruteng.

\section{Result and Discussion}

Based on the method and series of implementation, the description of the activities of the Co-19 Response Church of the Diocese of Ruteng follows the following stages and processes.

\section{Coordination}

Internal and cross-sectoral coordination is first carried out with the Task Force through face-to-face meetings and 'virtual' contacts. This cross-sectoral coordination was followed by a joint meeting of the Manggarai Police Chief, ending with an information dissemination of the Decree of the Indonesian Police Chief in the Ruteng. After conducting cross-sectoral coordination as shown in Figure 1 the Covid-19 Church Response Unit of Ruteng Diocese coordinated internal The Ruteng Sufficiency Task Force, located in the capital cities of Manggarai, West Manggarai and East Manggarai regencies.

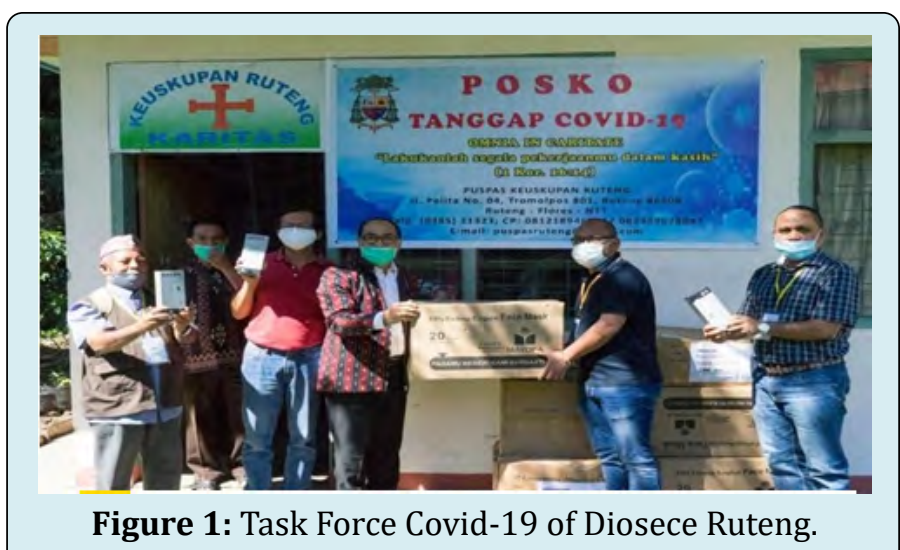

\section{Action}

Formally and in detail the action activities of the Covid-19 Task Force of the Ruteng Diocese Church began with the solidarity support activity announced by the Team 
and Covid-19 command post. Some have handed over aid directly to the Command Post in the form of goods and money. This action activity continued with promotion activities to prevent the spread of Covid-19 continuously through the Ntala Gewang radio media of the Ruteng Diocese Church as shown in Figure 2.

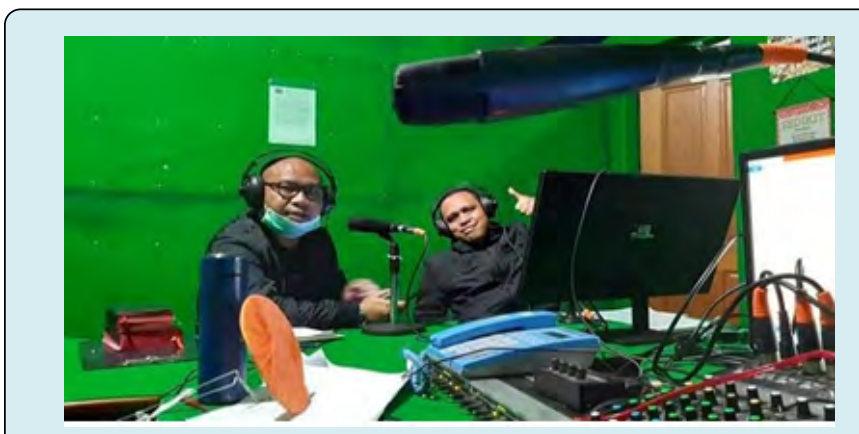

Figure 2: Talks how in Radio about Covid-19.

The first relief activity was carried out on March 16, 2020 to the Ben Mboi General Hospital in the form of simple personal protective equipment and food supplements as shown in Figure 3. In collaboration with the secretariat of the Church Catholic Diocese Ruteng, the Instruction of the Bishop Ruteng related to the Covid-19 Outbreak, which was then distributed to the Parishes throughout the Church Catholic of Diocese Ruteng.

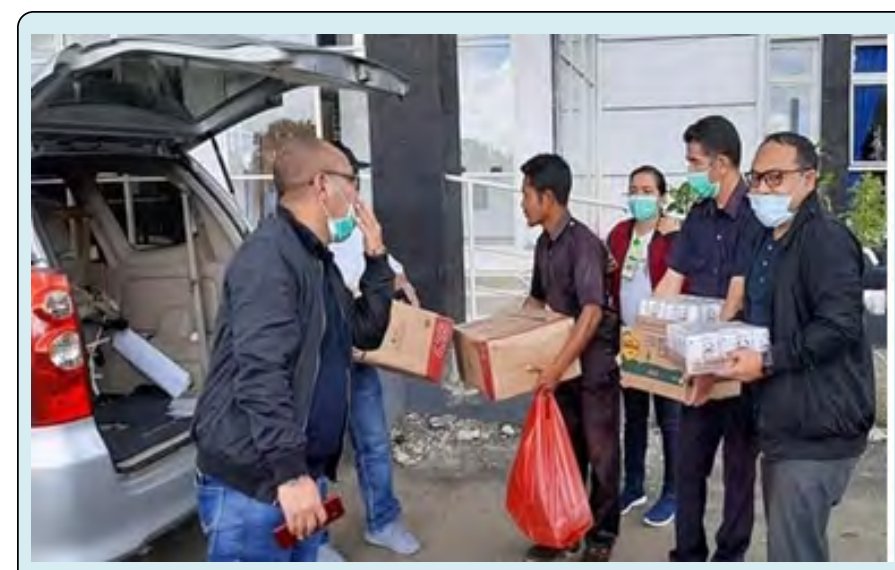

Figure 3: Distribution of basic food assistance to Communities.

In order to make the public more aware of the dangers of Covid-19, the Task Force Church Catholic Counseling conducted relief of Plastic Coat Personal Protective Equipment aid at Ben Mboi Ruteng General Hospital and spraying disinfectant in diocesan homes as shown in Figure 4. Subsequently, after coordination with the Parishes, disinfectants and spraying were carried out throughout the Ruteng Diocese Center area and several churches in Ruteng.

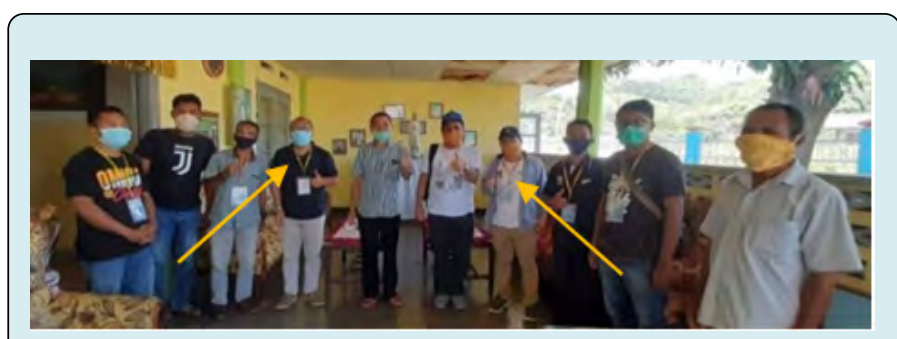

Figure 4: Task Force of Diocese Ruteng in one of the activities at Borong Parish.

The Covid-19 Task Force of the Church Diocese Ruteng carried out relief aid to the Borong parish as shown in Labuan Bajo parish and the Reo and Ruteng parish. The types of assistance in the form of plastic coats, gloves, boots, Dancow milk, Bear Brand milk, disinfectants and hand sprayers. Furthermore, to educate the public, 4000 copies of leaflets were also distributed to a number of ecclesiastical groups and various spiritual communities in the diocese of Ruteng.

The activity of the distribution of aid to the Parish task force (Reo, Borong, and Labuan Bajo) by the Covid-19 response group of the Church Ruteng Diocese is still ongoing, until the Covid-19 distribution curve has completely disappeared from the face of the earth. And for the sake of this solidarity movement, we, who are members task force of the Church Ruteng Diocese Covid-19, ask for the involvement of parties such as parish priests to urge families to proactively report newcomers or families returning on vacation from the local village head to be recorded and noticed by Covid's $19^{\text {th }}$ Regional task force.

\section{Action Plan}

As for several proposed solutions made to respond to this critical evaluation, namely: (1) Carry out an ongoing approach with the regional government task force; (2) Maintain, improve, expand coordination and network of cooperation with other parties (non-state); (3) Improve the internal coordination of the Team, especially with divisions. This solution offering will be followed by further activity plans, such as: (1) Re-coordinating with the Regional Government Task Command. Important coordination also with the Manggarai Regional Police in matters of 'social order' in accordance with the information of the head of the Indonesian police; (2) Optimizing the activities of the Parish Command Post for the data collection of newly arrived residents from areas exposed to Covid-19; (3) Optimizing the promotion and prevention of the distribution of Covid-19, which has already been carried out through the Radio, and soon follows through the distribution of simple leaflets to Parishes and parishes; (4) Internal Covid-19 solidarity fundraising (parishes, monasteries, communities, 
Ruteng diocese scope institutions; (5) Procurement of goods (medical and non-medical) for various Command Post activities and Parishes; (6) Distribution of aid for medical items and non-medical services to the Hospital and other groups; (7) Distribution of nine staples to vulnerable families affected by the Corona virus outbreak.

The awareness of this ecclesiastical service cannot be separated from the dynamics of the Church's views and attitudes in particular and religion in general towards problems in the world, and how to solve these problems through various critical-analytical and solutive studies. The existence of critical awareness to actualize and contextualize various Church social charity teachings with the reality of community life, as well as the opportunity to translate and interpret these teachings in people's daily lives, causes the Church to be motivated to empathize in solving problems that occur in the community.

Departing from this awareness, the Church has always been proactive in responding to the demands of the times and all forms of change, and remains an institution that has commitment and consistency in advocating, accommodating and facilitating the needs and hopes of the people. The church's effort in making people aware of the fact of suffering and the cause of suffering is one of the nature and goals of transformative diaconia. Through various forms of awareness activities such as education, promotion, prevention and curation, deaconia directs every community / community to always have an optimistic sense of life [4-12].

Through various variants of educational, promotional, prevention and curation activities, ecclesiacic dionia targets the changes in people's lives, both from the political, social, and economic aspects, education, health and culture [6,7]. By emphasizing the basic concept of awareness, ecclesiacic dionia is directed at increasing the degree and quality of life, the loss of various forms of discrimination, injustice and oppression, and the formation of a healthy, prosperous, just and prosperous social order 810 . At this level, transformative ecclesiastical dionia can be preventive, promotive and educative or curative and problem solving. The community is made aware of how to keep their lives balanced, normal, sustainable, healthy and long-lived $[11,13]$.

The urgency of the Church's attention to health problem, revealed by Pope Francis at the 27th World Day of the Sick, June 2019: "The Church is a defense of the sick, especially those who suffer from illness who need special assistance. Your voluntary work in medical institutions and in homes, from providing medical care to offering spiritual assistance, is very important. Countless people who are sick, alone, elderly or mentally or physically weak, have benefited from the ministry of the diocese Ruteng to continue to be a sign of the Church's presence in an increasingly secular worldly world" [14].

\section{Evaluation}

In carrying out this activity together with the Curch Catholic of Diossece Ruteng, several evaluative notes. First, the lack of coordination between the teams has not led to smooth activity. In addition, the relevant parties have not realized the urgency of the handling of Covid-19 as a form of service the Ruteng diocese church to save lives from the community in the Ruteng diocese. Second, Task Force of the Church Diossece Ruteng does not yet have a roadmap for the Covid-19 handling strategy. In addition, the challenge in carrying out this activity is the emergence of fear, both within the cluster team and the Manggarai community, for the transmission of this virus within themselves. Psychologically, working in fear causes all plans and stages of activities to not run smoothly and effectively [13].

\section{Conclusion}

Covid-19 is a challenge as well as an opportunity for strategic praxis in religious service. With the power of coordination, action, evaluation and action plans, the Church Catholic of Diocese Ruteng also increasingly able to actualize itself as an institution offering salvation 'now and here', especially for the salvation of the sick. Poor families who are increasingly affected by economic conditions due to the Covid-19 pandemic feel the presence of the Catholic church to meet their basic needs while raising their dignity and dignity as human beings who are worthy of life now and in the future.

\section{Acknowledgment}

We give appreciation to the Bishop of Ruteng, the Regent of Manggarai, Manggarai Timur, and Manggarai Barat, the Heads of Sub districts and Parish Priests who have helped the author provide data and information in completing the writing of this scientific paper. There is no conflict of interest in this study.

\section{References}

1. Yusuf AA (2020) Measuring the "Real" Economic Costs of The Covid-19 Pandemic.

2. (2019) The Central Statistics Agency of East Nusa Tenggara Province. 2019. Percentage of Poor Population in March 2019 rises to $21.09 \%$.

3. Abineno Ch JL (2006) Practical Guidelines for Pastoral Services. Jakarta: BPK Gunung Mulia. 
4. Gale, Rebecca (2020) Its 'social distancing' the wrong term? Expert prefers 'physical distancing,' and the WHO agrees.

5. Oentoro, Jimmy (2010) Dream Church: Becoming an Influential Church. Jakarta: Gramedia.

6. Singgih, Gerrit E (2004) Anticipating the Future: Doing Mythology in Context at the Beginning of the Third Millennium. Jakarta: BPK Gunung Mulia.

7. Kartini K (2014) Social Pathology. Rajawali Pers: Jakarta.

8. Chomsky N (1978) Human Rights and American Foreign Policy. New York: Oxford University.

9. Kinch JW (1974) Social Problems in the World Todays. London: Addison-Wesley Publising Company.
10. Andrea P (2020) How faith communities are responding to the coronavirus pandemic. The Conversation.

11. Ministry of Health of the Republic of Indonesia (2018) Health Research 2018.

12. Jack Z (2007) Social Studies for The Twenty-First Century; Methods and Materials for Teaching in Middle and Secondary Schools. New Jersey: Lawrence Erlbaum Associates.

13. Bertrand R (2007) The Problem of Fhilosophy, (terjem.) Colombus, Ohio, New Jersey: Merrill Prentice Hall.

14. Mirifica News (2019) Indonesian Church Guardian Conference. 